\title{
Archival Ethics: The Truth of the Matter
}

\author{
Richard J. Cox \\ School of Information Sciences, University of Pittsburgh, 648 LIS Building, 135 N. Bellefield Avenue, Pittsburgh, \\ PA 15260. E-mail: rcox@mail.sis.pitt.edu
}

\begin{abstract}
This essay explores the question of whether records professionals are as aware of the ethical dimensions of their work as they should be. It consider first the historical and professional context of archival ethics, then examines a recent case about business archives involving the author that suggests the need for renewed attention to professional ethics, and concludes with a discussion about how archivists might reconsider the ethical dimensions of their work.
\end{abstract}

The task of the philosopher is neither to belittle truth nor to exalt it, neither to deny it nor to defend it, but to explain why we need the concept and what it is to possess it. (Dummett, 2004, p. 116)

\section{Introduction}

We live and work in a time when there are many challenges to archives and records management. National security, privacy, intellectual property, a fragile digital documentary heritage, and a host of other issues require that society's records keepers be vigilant about technical, administrative, legal, and ethical matters (see Harris, 2005). These turbulent times require archivists to buoy public faith in the trustworthiness of archival institutions and the people who work there, and "they [archivists] must be able to make reference to codified ethics in order to proffer a justification for that faith" (Dingwall, 2004 , p. 20). Yet, the growing number of writings in the past decade in the international archival community about matters of recordkeeping and accountability, public policy, and societal issues have occurred apart from the writings about professional ethics. Not only are there reasons for why this has happened but there are consequences as well.

Archivists and records managers strive to work ethically, both groups possessing ethics codes, regularly reading about ethics in their professional literatures, and attending conference sessions and workshops on this topic. This essay explores the question of whether records professionals are as aware of the ethical dimensions of their work as they should be.

(C) 2008 ASIS\&T • Published online 15 April 2008 in Wiley InterScience (www.interscience.wiley.com). DOI: 10.1002/asi.20852
I consider first the historical and professional context of archival ethics, then examine a recent case about business archives involving the author that suggests the need for renewed attention to professional ethics, and conclude with a discussion about how archivists might reconsider the ethical dimensions of their work. Since there is no clear consensus about the particulars of archival ethics, what I am writing here may be received by some as being controversial, misguided, or even misinformed. It is why records professionals must rethink this aspect of their work.

\section{The Background of Archival Ethics}

In 1980, the Society of American Archivists (SAA) approved its first official ethics code; since then, it has been revised twice (in 1992 and again in 2005), about the same time as the more broadly defined information professions were grappling with this area (M.M. Smith, 1997). Prior to this SAA code, the National Archives had adopted a document in 1955 called "The Archivist's Code," functioning as the semi-official ethics guide for the North American profession until SAA's efforts. The earliest SAA code seemed designed for display (like that of its National Archives and Records Administration predecessor) while the 1992 code, with an ample commentary, was designed for use (or so that was part of the reasoning behind it). The most recent version has removed the commentary, reflecting the SAA leadership's convictions that the code is not enforceable, that it subjects the Society to potential legal liability, and that the code with commentary muddles its meaning and usefulness (Benedict, 2004).

Through these decades of discussion about archival ethics codes, we can discern their general limitations. The Association of Records Administrators and Managers' (ARMA) adoption of a code a decade and a half after the first of SAA's codes suggests such weaknesses, with an emphasis primarily to claim professional status (an ethics code being a benchmark for this) rather than providing any directives that can be monitored or enforced (Lytle, 1998; Pemberton, 1996, 1998).

Archivists and records managers have been writing about ethical issues for a number of decades, although not as much 
as on other topics (at least, until very recently). In 1982, Karen Benedict urged that "particular attention should be paid to the subject of ethics for business archivists, because their positions and responsibilities are somewhat different from the rest of the profession and include a higher probability of involvement in protracted litigation" (p. 314). American archivists, beyond discoursing on the general parameters of the SAA ethics code at various times (Horn, 1989), also have focused their attention on certain aspects of archival functions and their ethical implications or challenges, such as access, processing, and collecting (Becker, 1983; Cain, 1993; Danielson, 1989, 1997; Miller, 1989; Wilsted, 1993). Archivists, internationally, also have reflected on a variety of ethical issues concerning the formulating of ethics codes (Cooke, 1987; Russell, 1976) as well as their basic functions such as preservation and access (Baynes-Cope, 1988; MacNeil, 1991).

By and large, however, the focus on ethics in the records professions has been on the role that codes play, usually the practical values clustering around the public responsibility of archivists and records managers (Hill, 1998, p. 74). We can speculate just how useful codes are in practice. Others have depicted the limitations of codes, with their focus on rules and procedures, in complex and ever-changing environments (Wengert, 2001), or simply have alluded to the range of concerns and challenges that extend far beyond what is represented in codes (Froelich, 1992). Obviously, it is far easier to consider conceptually the role, content, and use of professional ethics codes than it is to explore specifically the murkier matters of ethical practice, failings, and successes.

Records professionals in the field usually demand more knowledge about computer applications or technical standards than about ethical approaches for their entry-level hires. It is a professional dilemma, one suggesting that archivists and records managers are both unsure about the primacy of ethics codes and the foundations upon which they are built, even though some give ethical matters more credence. In a discussion about records retention scheduling in law firms, Barr, Chiaiese, and Nemchek (2003) observed that "Unlike many types of corporations and businesses whose recordkeeping practices are regulated by statutes and/or administrative regulations, records retention practices in the legal environment derive from ethical and/or disciplinary rules governing lawyer behavior" (p. 266). This characteristic may not be universal, however, as some archivists and records managers such as in corporations have adopted a market-centric definition of their work, potentially diminishing the role of ethical considerations.

There are challenges with professional ethics, often generated by defining such concepts as ethics or accountability. For many, ethics implies a philosophical or religious matter, and we would be wrong to ignore the implications of such elements. No one should discount this aspect when they consider that archives, libraries, and museums and their documentary and artifact collections are often targeted for destruction because of their religious, cultural, and other symbolic values (Knuth, 2003; Raven, 2004) or, for example, that individuals with strong religious perspectives can provide illuminating insights into ethical and moral challenges (Carter, 2005). And it is especially significant for archivists and records managers, particularly those working in corporations, when they consider that some forms of financial records are reflective of religious attitudes from centuries ago (Aho, 2005).

When I use ethics or accountability, I am focusing on applied concepts such as choosing right over wrong, recognizing that we can often debate the nuances of what might be right or wrong but that we cannot ignore such aspects in our work (Truth in records or truthful records is a fundamental part of the legacy of archival and records management theory and practice.) Anita Allen (2004) provided a sense of what I mean by ethics: "Workplace ethics require diligence, excellence, pride of accomplishment, and integrity. The kind of integrity required begins with honesty, respect for the person and property of others, and self-control" (p. 111). This is close to what some have termed ethical thinking, understanding that "human behavior has consequences for the welfare of others," and that there is a "common core of general ethical principles" (Paul \& Eder, 2003, p. 2). This is a definition that often captures at least part of the reasons why organizations and individuals keep and administer their documents and the information contained in them.

What do I mean by accountability, a term only beginning to be analyzed closely? (Meijer, 2000). I use accountability to refer to processes related to individuals and organizations answering to a higher authority, the assessment of compliance and carrying-out of required activities and functions, and reporting on the effectiveness of performing certain tasks and responsibilities. Accountability brings together, under one umbrella, notions of responsibility, liability, laws and regulations, and transparency of activities. In terms of archives, records, and information, accountability assumes issues such as explaining the importance of records, working against unwarranted secrecy, the importance of corporate and societal memory, and trust that is necessary between government and its citizens (Cox \& Wallace, 2002). Accountability and ethics go hand in hand.

\section{Corporate Archives and the Ethical Quest}

For a while, corporate scandals replaced government ones as the focal point of ethical, legal, and policy controversies in society as well as in the records professions. The Enron/Arthur Andersen scandals and the dramatic stories of the shredding of Enron's records and the collapse of auditing practices gained extensive media coverage as well as generated insider accounts and caused the refurbishing of business management books that had made Enron an exemplar of innovation. The kinds of professionals who work for these entities, including archivists and records managers, must consider ethical matters as an essential aspect of the administration of records and information.

In a recent history of the corporation, the commentators offered this historical note about corporations and ethics: 
"In general, companies have become more ethical: more honest, more humane, more socially responsible" (Micklethwait \& Woolridge, 2003, p. xx). While indeed some companies such as Lockheed Martin have established major ethics programs, the results of such programs are "difficult and controversial" to ascertain (Terris, 2005, p. 4). To my knowledge, there have been no studies of corporations with ethics programs concentrated on records management, except for the ironic descriptions of Enron's stress on both an ethics code and a corporate consulting program for businesses interested in strengthening their workers' sensitivity to ethical matters.

Ethics codes can become useless in the corporate environment that has spun out of control. And records managers and archivists should have plenty of reason to reconsider and recommit themselves to the importance of professional ethics and accountability, especially as measures to counter such corporate shenanigans (e.g., the Sarbanes-Oxley Act of 2002) dictate many new recordkeeping measures potentially transforming what such records professionals do. Although the long-term implications of these scandals and the various legislative and regulatory responses cannot yet be seen, it is clear that they have shone public light on records management practices such as records destruction that were not previously well understood. At the least, archivists and records managers are operating in a new kind of environment where ethical conduct, compliance, and accountability are more prominent as the factors defining their mission and driving their work.

The importance of corporate ethics or corporate social responsibility has intensified greatly, with an immense outpouring of writings about such concerns (see Brown, 2005; Vogel, 2005). Has this movement had any impact on corporate archives and their thinking?

Despite the growth of interest in corporate ethics and social responsibility matters, there is little in the business archives or records management literature that addresses this topic. While the business archives and records management literature is not extensive, there are a number of substantial essays where one might expect discussion of ethical matters, among the many other issues considered. Yet, despite the obvious ethical challenges corporate archivists face, these professionals seem not to have engaged with this aspect of their work. Prominent business archivist Elizabeth Adkins (1997), in her fine assessment of the development of American business archives just about a decade ago, hardly mentions any aspect that might be termed ethical, probably reflecting the general lack of attention to this topic in the literature and profession to that point. Fifteen years before Adkins's effort, overviews of American corporate archives generally included no mention of ethical issues, often trying to make the case about how much of an asset an archives program could be (Anderson, 1982; D.R. Smith, 1982). The emphasis on the corporate archivist serving the corporation and its business interests seemed to dominate the writings of many such professionals (Coulson, 1993; Rabchuk, 1997). Essays about particular types of corporate archives usually gloss over ethical issues, even when focusing on basic questions and concerns supporting or detracting from archival operations. It should be the case that as corporate archivists have tried to relate their mission to their role in supporting their employing business, they also should identify where there may be ethical and legal problems in taking on such an agenda.

For archivists to become capitalists and serve their employers' needs seems fine, but what about matters such as professional ethics? Certainly business archivists must connect their mission and activities to those of their for-profit employers, and there have been excellent assessments of this relationship (G.D. Smith, 1982); yet, to relegate professional ethics and other public good responsibilities under the financial bottom line seems foolhardy at best. Deborah Gardner, commenting on the 1982 cluster of articles on business archives published in the American Archivist, did not mention ethics as a concern, believing that the case for their programs is "keyed to justifications that clearly define the archival function as part of corporate culture and organization," including being an "income-producing center" and relegating the use of the archival resources by scholars and other researchers as being "an important public service" but primarily one as valued as an asset to the corporation itself (pp. 294-295).

Some observers have hinted at the ethical problems facing corporate archivists and records managers. Historian Duncan McDowall (1993) speculated as follows:

\begin{abstract}
One suspects that the litigiousness of our times ... has bred a conscious impulse in many executives to avoid the keeping of any written record of how and why decisions were made. This same impulse, often combined with an abiding instinct for self-preservation within the corporation, may explain why so many executives regard archivists and their purpose with suspicion. (p. 352)
\end{abstract}

English archivist Leonard McDonald (1989) worried that "in the world of business ... the archivist still tends to adopt the role of the medieval archivist-defending his master's claims to intellectual property against attack by others" (p. 169). McDonald worried as well about the perceptions of the archivist, the division in professional cultures, and their clientele. He noted, for example, that archivists

tend to look harder at what we regard as ethical responsibilities than does general management. General management, with its expressed intention of responsibility to the shareholder and to the successful continuity of the Company, has its own singleminded sense of priorities and ethical responsibilities. (p. 171)

Other corporate archivists have expressed similar concerns (Bakken, 1982; Van Camp, 1982).

\section{The "Sun Mad" Poster Controversy and Archival Ethics}

Recently, a minor controversy occurred regarding the use of a political poster on the cover of the American Archivist that reflects the challenges of archival ethics in the corporate 
sector and that speaks, in my opinion, to the lack of development of archival ethics. It is a painful and difficult matter to write about both because it involves myself and because it is so easily open to misinterpretation. My intent here is not to accuse anyone of unethical conduct, but I do believe that the poster controversy does suggest something of the political, professional, and societal environments that influence how archivists and records managers view ethical matters.

Two letters and an editor's column were published in the Fall/Winter 2004 issue of the American Archivist regarding the use of a political poster (originally created in a campaign against the Sun Maid Corporation, with the poster redrawing and parodying the well-known corporate logo to be "Sun Mad") on the cover of the Fall/Winter 2003 issue of the same journal (Eppard, 2004). The poster accompanied an essay on political poster collections (Tschabrun, 2003). A group of business archivists and another prominent archivist complained that the cover "disturbed" them, believing that the illustration denigrated corporate archives or archivists working with corporate records and opened the SAA to legal risk. The editor's reasoned response about the criticisms indicated that he had the SAA's legal counsel review the use of the poster and expressed his belief that the journal serves the "whole archival profession," suggesting that disagreement about the journal's content and covers always may be present (Eppard, 2004). The controversy spurred me on to write my own letter to the editor, published in the subsequent issue of the journal and summarized here (Cox, 2005).

The problems presented in this case relate primarily to the matters of offending individuals and organizations, as well as raising the matter, most important to the present essay, of the mission of corporate archives. In my letter to the editor, I bluntly asked "Is the mission of corporate archives only to make their organizations look good or to serve a public relations purpose?" What about the values of records and their management for purposes such as legal compliance, evidence of corporate activities, and accountability? If a company found such negative documents and artifacts in their possession such as the political poster used on the journal cover, would it destroy or bury the objects?

Corporations, and how they administer their records and information, have always been controversial as recent corporate scandals, leading to new efforts to regulate corporate accounting practices as witnessed in the Sarbanes-Oxley Act, indicate. What intrigues me is how the individual functioning as an archivist or a records manager can work in the corporate environment in any realistic way, adhering to any sense of professional ethics or mission, without some serious reflection about the practical implications both of his or her work and professional behavior codes and standards. Records can be, by their very nature, inherently controversial. They document good and bad actions, the activities of evil and exemplary people and organizations, the decisions by corrupt and stellar government officials and corporate leaders, and the activities of strong and weak university administrators and faculty members (just as examples). And it might be added that records, due to their power as memory and cultural symbols, inspire strong feelings, just as the blatantly controversial "Sun Mad" poster does.

What this case illustrates is professional self-censorship, reflecting trends in our society that cannot bode well for the archival mission. Corporations administering records only to make themselves look good can hardly be said to understand larger questions about their role in the commonweal. Moreover, they will fail if they strive to manipulate their own documentary heritage in such a way. However, the bigger question is where archivists and records managers will be and what they will be doing in organizations with such an agenda. This is the ethical dimension.

The controversy has continued, I suspect because of a sentence in my letter, repeated in this essay: "What intrigues me is how the individual functioning as an archivist or records manager can work in the corporate environment in any realistic way, adhering to any sense of professional ethics or mission." For a while, I regretted writing the letter because of this, but I am now convinced, more than ever, that at the heart of the controversy is a fundamental issue relating to archival ethics, one we have often seemed to avoid dealing with by focusing on code writing. This is what I have tried to explain more fully in this essay.

Others will continue to have other perspectives about this matter as well as about what is entailed in what we think of as professional ethics. Indeed, this was brought home when the immediate past and current SAA presidents published their thoughts on the cover controversy in another issue of the American Archivist (2005, Vol. 68). Randall Jimerson and Richard Pearce-Moses acknowledged that the controversy had "raised important questions for professional debate about how archivists define our professional responsibilities" (p. 202), but they also expressed concerns "that it is important to receive expressions of concern from our members with due consideration and respect" (p. 202). Mostly, they opined that "we should be especially careful to avoid even the appearance of questioning the ethics of an entire segment of our members" (p. 203), and that this is important in respecting the "need for diversity in the archival profession, and it seeks to ensure that all who are interested in protecting the historical record feel welcome" (p. 203). Except for this essay, their letter brings to a close the "Sun Mad" poster controversy. My only additional comments are that questioning a particular group's position in such a debate, one clearly expressed in their own criticism of others' actions, should not be interpreted as reflecting on their motives and ethics; however, there are certainly elements of this debate that reflect ethical challenges.

This controversy provides no evidence, of course, that any corporate archives or records management program is destroying in any deliberate fashion records to protect a business or to provide the best face of the corporation. What it reveals is a set of attitudes suggesting that individuals in the field may be ultrasensitive to the possibility that certain activities may lead to negative press, jeopardizing programs and careers. Whether this kind of thinking violates the spirit of the relevant professional ethics codes is a matter others should debate, but I submit that at best we ought to be troubled about 
such attitudes. In an environment where we have weak ethics codes, with no enforcement procedures, along with attitudes suggesting that records professionals may operate out of fear of drawing negative attention to their programs, we ought to be concerned whether we can operate effectively in an ethical fashion or, more importantly, that we can build trust with our employers, constituents, and the public.

\section{Conclusion}

These are dangerous, interesting, and exciting times to be an archivist or records manager. Given what records professionals do and the access to evidence they have, just what are their ethical responsibilities in society and organizations? When might they, for example, need to become "whistleblowers"-individuals who place the welfare of society and its inhabitants over their own? This is an interesting question hardly being addressed within the archival and records management community, but one that will be asked more frequently, I think, in the future.

There are many practical ethical issues we could consider that the archivist or records manager might face. Since records professionals work across their organizations and have access to most, if not all, the information being generated, it is logical to assume that they will discover illegal activities, wrongdoing, and ethical lapses as soon as anyone else in their workplace. Archivists and records managers have not really addressed the consequences of such possibilities, instead choosing to focus on the ethics of their own practice-such as providing equal access to all researchers, not acquiring documentary materials of questionable origins and ownership, and not falsely accusing other archival programs and records professionals of unprofessional practice. These are all important concerns, of course, but they are inwardly focused on activities that must seem like arcane professional activity to outsiders and that hardly address the major ethical matters of the day. The real ethical challenges facing archivists and records managers have more to do with the shifting shapes of the roles of governments and other organizations such as corporations that create a considerable portion of the records and employ many working records professionals.

Archivists and records managers generally believe that records are important and that they make a difference in society, although sometimes they seem to waffle as much as any other group about just what this means. They do not want to be seen as clerks or secretaries, so they develop elaborate new justifications for their roles, usually tying into the glitzier aspects of the information or knowledge society while moving them farther from their main responsibility—records. While some of this falls well within the normal range of professional debate and navel-gazing, some of this also weakens archivists and records managers generating a coherent vision and articulating a clear mission. Yet, these matters are hardly as serious as the question of whether archivists and records managers ought ever to be whistle-blowers, grabbing onto a higher ethical norm that demands their seeking a different role in contributing to the public good.
Whistle-blowing-"employees' reporting of illegal, immoral, or illegitimate activities to parties who may be able to take action" (Miceli \& Near, 1988, p. 267)—is rising in frequency, but it is an issue that has received little attention by records professionals. Why have records professionals not addressed this issue? The obvious answer is, of course, that whistle-blowers destroy their careers and livelihoods, no matter how right they may seem to be in the public forum; but this seems too obvious an explanation. More to the point may be that records managers and archivists tend to be loyal to their organizations, and confused by what their societal roles might entail. They are, for example, bombarded by advice about records retention and destruction instructing them to protect their organizations.

Records professionals may be ill equipped at this point to consider the consequences of whistle-blowing, or they may lack self-confidence or believe that they are powerless given their professional status and public profile. It is difficult, of course, to firmly state when someone should go public and threaten him- or herself with professional self-immolation.

I am not offering a precise list of circumstances that would indicate when an archivist or records manager should break ranks and speak out. Not only are there so many variables at play in this but I must admit that I have not formed in my own mind a completely satisfactory picture of what is involved; but like Dummett's (2004) explication of the relationship of philosophy and truth, archivists and other records professionals need to understand why they need the concept of ethics and practical expressions of ethical behavior, such as whistle-blowing, to influence their work. Hopefully, what I offer will generate some dialogue, enabling archivists and records managers to understand better their responsibilities in their organizations and society. In some instances, what may need to be involved is no more than revisiting what people have said in the past about ethical issues. For example, nearly two decades ago, the ARMA ethics code was described as including the "principle of the free flow of and access to information in society as a necessary condition for an informed populace and maintenance of democratic processes" and to "strongly resist, therefore, any pressure or subornation to mishandle or misuse information or records-even when proper handling may have an adverse affect on the organizations for which they work" (Pemberton, 1998, p. 6); one can wonder how this relates to some of the issues recently on the minds of some corporate archivists.

In the meantime, the archival and records management community needs to engage in a number of initiatives relating to ethics issues. Despite a fairly steady stream of writing about ethical matters, there is essentially no research on such concerns. Archivists and records managers need to go beyond the business of creating ethics codes and instead need to begin to consider just what roles they really play within their employing institutions. Historian McDowall (1993), in mulling over the place of the archivist in the corporation, suggested that historians and archivists can "bring a disinterested, fresh, and valuable viewpoint to the work of the corporation. We can be part of the corporation, but not 
necessarily its creature" (p. 356). He did not offer any practical insights into what such a disinterested role might be, but that is certainly something records professionals need to reconsider, and in earnest.

\section{References}

Adkins, E.W. (1997). The development of business archives in the United States: An overview and personal perspective. American Archivist, $60,8-33$.

Aho, J. (2005). Confession and bookkeeping: The religious, moral, and rhetorical roots of modern accounting. Albany: State University of New York Press.

Allen, A. (2004). The new ethics: A guided tour of the twenty-first century moral landscape. New York: Miramax Books.

Anderson, H.P. (1982). Business archives: A corporate asset. American Archivist, 45, 264-266.

Bakken, D.A. (1982). Corporate archives today. American Archivist, 45, 279-286.

Barr, J., Chiaiese, B., \& Nemchek, L.R. (2003). Records management in the legal environment: A handbook of practice and procedure. Lenexa, KS: ARMA International.

Baynes-Cope, A.D. (1988). Ethics and the conservation of archival documents. Journal of the Society of Archivists, 9, 185-187.

Becker, R.L. (1993). The ethics of providing access. Provenance, 11, 57-77.

Benedict, K. (1982). Business archives literature. American Archivist, 45, 312-314.

Benedict, K. (2004). An evolution in a code of ethics: The Society of American Archivists. International Congress on Archives. Retrieved March 17, 2008, from www.wien2004.ica.org/imagesUpload/pres_36_BENEDICT_ SPA01.pdf

Brown, M.T. (2005). Corporate integrity: Rethinking organizational ethics and leadership. New York: Cambridge University Press.

Cain, V.J.H. (1993). The ethics of processing. Provenance, 11, 39-55.

Carter, J. (2005). Our endangered values: America's moral crisis. New York: Simon \& Schuster.

Cooke, A. (1987). A code of ethics for archivists: Some points for discussion. Archives and Manuscripts, 15, 95-104.

Coulson, J. (1993). Our professional responsibility. Records Management Quarterly, 27, 20-25.

Cox, R.J. (2005). American archivist cover controversy. American Archivist, $68,8-11$.

Cox, R.J., \& Wallace, D.A. (Eds.). (2002). Archives and the public good: Accountability and records in modern society. Westport, CT: Quorum Books.

Danielson, E.S. (1989). The ethics of access. American Archivist, 52, $52-62$.

Danielson, E.S. (1997). Ethics and reference services. In L.B. Cohen (Ed.), Reference services for archives and manuscripts (pp. 107-124). New York: Haworth Press.

Dingwall, G. (2004). Trusting archivists: The role of archival ethics in establishing public faith. American Archivist, 67, 11-30.

Dummett, M. (2004). Truth and the past. New York: Columbia University Press.

Eppard, P.B. (2004). Judging a book by its cover. American Archivist, 67, 156-160.

Froehlich, T.J. (1992). Ethical considerations of information professionals. Annual Review of Information Science and Technology, 27, 291-324.

Gardner, D.S. (1982). Commentary II. American Archivist, 45, 294-295.
Harris, V. (2005). Ethics and electronic recordmaking. In J. McLeod \& C. Hare (Eds.), Managing electronic records (pp. 115-128). London: Facet. Hill, M.W. (1998). Facing up to dilemmas: Conflicting ethics and the modern information professional. Aslib Proceedings, 50, 71-78.

Horn, D. (1989). The development of ethics in archival practice. American Archivist, 52, 64-71.

Jimerson, R.C., \& Pearce-Moses, R. (2005). Letters on the American archivist cover controversy. American Archivist, 68, 202-203.

Knuth, R. (2003). Libricide: The regime-sponsored destruction of books and libraries in the twentieth century. Westport, CT: Praeger.

Lytle, R.H. (1998). Ethics of information management. Records Management Quarterly, 4, 5-8.

MacNeil, H. (1991). Defining the limits of freedom of inquiry: The ethics of disclosing personal information held in government archives. Archivaria, $32,143-144$.

McDonald, L. (1989). Ethical dilemmas facing an archivist in the business environment: The constraints on a business archivist. Journal of the Society of Archivists, 10, 168-172.

McDowall, D. (1993). "Wonderful things:" History, business, and archives look to the future. American Archivist, 56, 348-356.

Meijer, A. (2000). Anticipating accountability processes. Archives and Manuscripts, 28, 52-63.

Miceli, M.P., \& Near, J.P. (1988). Individual and situational correlates of whistle-blowing. Personnel Psychology, 41, 267-282.

Micklethwait, J., \& Woolridge, A. (2003). The company: A short history of a revolutionary idea. New York: Modern Library.

Miller, H.L. (1989). Will access restrictions hold up in court: The FBI's attempt to use the Braden Papers at the State Historical Society of Wisconsin. American Archivist, 52, 180-190.

Paul, R., \& Elder, L. (2003). The miniature guide to understanding the foundation of ethical reasoning. Dillon Beach, CA: Foundation for Critical Thinking.

Pemberton, J.M. (1996). Who cares about records management? Social relevance and professional standing. Records Management Quarterly, $30,52-57$.

Pemberton, J.M. (with Pendergraft, L.O.). (1998). Toward a code of ethics: Social relevance and the professionalization of records management Records Management Quarterly, 32, 51-56.

Rabchuk, G. (1997). Life after the Big Bang: Business archives in an era of disorder. American Archivist, 60, 34-43.

Raven, J. (Ed.). (2004). Lost libraries: The destruction of great book collections since antiquity. New York: Palgrave Macmillan.

Russell, E.W. (1976). Archival ethics. Archives and Manuscripts, 6, 226-234. Smith, D.R. (1982). An historical look at business archives. American Archivist, 45, 273-278.

Smith, G.D. (1982). Dusting off the cobwebs: Turning the business archives into a managerial tool. American Archivist, 45, 287-290.

Smith, M.M. (1997). Information ethics. Annual Review of Information Science and Technology, 21, 339-366.

Terris, D. (2005). Ethics at work: Creating virtue in an American corporation. Waltham, MA: Brandeis University Press by University Press of New England.

Tschabrun, S. (2003). Off the wall and into a drawer: Managing a research collection of political posters. American Archivist, 66, 303-324.

Van Camp, A. (1982). Access policies for corporate archives. American Archivist, 45, 296-298.

Vogel, D. (2005). The market for virtue: The potential and limits of corporate social responsibility. Washington, DC: Brookings Institution Press.

Wengert, R.G. (2001). Some ethical aspects of being an information professional. Library Trends, 49, 486-509.

Wilsted, T. (1993). Observations on the ethics of collecting archives and manuscripts. Provenance, 11, 25-37. 